\title{
IMPATIENT ACCUMULATION, IMMEDIATE CONSUMPTION
}

\author{
Problems with Money and Hope in Central Kenya
}

Peter Lockwood

\begin{abstract}
Contemporary anthropological accounts of economic uncertainty often use the concept of hope as a means of recovering human agency in relation to broader socio-economic structures. At times, however, the emphasis anthropologists place on hope can appear too generically existential. This article argues for a more specific emphasis on the object of hope-an appreciation of more concrete desires held by marginal persons, orienting their economic activity. In the case I unfold from peri-urban central Kenya, low-status male youth are shown to lack the money they require to unlock pleasurable experiences of drinking, a sign of having wealth and the living of a good life. Rendered hopeless, young men turn to crime as an alternative means of realizing their desires for consumption in the short term.
\end{abstract}

Keywords: accumulation, consumption, crime, desire, hope, indeterminacy, Kenya, money, youth

"We like comparing ourselves with people whose lives we cannot reach" (twendaga kwĩganania na andũ tũtangîkinyĩra maica mao). These were the words of 24-year-old Iregi, one of a group of young men whom I had come to know in the town of Chungwa on the peri-urban outskirts of Nairobi in southern Kiambu County. ${ }^{1}$ I had met Iregi at a cafe (mkahũa) in the center of town where he would sometimes hang out with other local youths and chew mũgũuka (cheap khat leaves sold at 50 KES for a small bag). ${ }^{2}$ It was there that Iregi usually waited alongside his peers for an opportunity to make a small amount of money, either by 'asking' (kũhoya) others to give him a few coins, perhaps a 50 KES 
note, or by taking a job offered by local market traders, such as transporting goods from the roadside and up the hill to Chungwa's marketplace.

It was April 2018, toward the end of fieldwork I carried out in Chungwa and its environs between January 2017 and July 2018. I met up with Iregi and Cassius (known as 'Cash' for short), another of my closest interlocutors from the town who came from a slightly more ‘well-up' background than Iregi. After having spent time with them throughout my stay in Chungwa, staying up late chewing mũgũuka and drinking together in bars and at their friends' houses, I wanted to pin down Iregi's life story. Since Cash had known Iregi for a long time, the two friends decided to speak to me together. In the dingy back room of the mkahũa, while the three of us sipped sugary milk tea, Cash and Iregi began talking about what had motivated them in their previous lives as petty criminals, often working side by side.

Switching back and forth between English, Kiswahili (in its Sheng creole), and Gikuyu, Iregi recollected his reasons for robbing pedestrians in Chungwa at nighttime:

Iregi: You see like Cassius, that boy [in] their home there is money [i.e., they are from a 'well-up' family]. Why can't I get [from] them my money? So you take advantage-beat people, beat up people.

Cassius: To be on that level! So that we can hang out. If they're going to this club, you want to go to this club. You're young-you don't want to be at home. But at the end of the day these guys didn't work for this money. They've been given [it] from their parents.

Iregi: When you find your friend has money, [and] you don't have. And you're trying to tell your friend, "Give me something. Give me something." He refuses. So when you go outside you see my friend has money, I don't have. [You think,] “I’m gonna steal that person and I'm gonna go back there [to the club] with my money."

Cassius: It's your money when you get it.

In an unequal context, socio-economic distinctions are keenly read and palpably felt through the medium of cash to be spent on the 'fun' (raha) of drinking. 'To reach for' (gükinyirra) the lives of others implies not only economic distance, sometimes a chasm of wealth between oneself and another person, but the desire to forcibly seize money to experience a life that is not one's own-a change of status, temporarily felt. 'Comparison' (kwiganania) implies envy, the desire to consume like others witnessed in the peri-urban milieu of central Kenya.

Iregi's words describe the central theme I explore in this article-a sense of being distant from what one desires, yet finding a way to appropriate it and experience it nonetheless through stolen money. What is desired is the lifestyle of those with wealth and the moments of fun (raha) such a life affords. 
Both Cash and Iregi live in a context where images of a good life defined by an abundance of cash are all too frequently glimpsed, whether in the actual persons they encounter hanging around Chungwa Town-successful Gikuyu businessmen driving expensive cars, for instance-or on the television screens of the video parlors they frequent for small amounts of cash to watch Hollywood movies. Images of wealth have an 'alterity', so to speak. When viewed, they serve as a powerful reminder to men like Iregi and Cash that they lack the money to experience them. Raha is a sign of a life well lived, and to simulate it is to simulate a life that is not one's own, since money is the facilitator of such conspicuous and enjoyable consumption.

This article describes the style of impatient accumulation and immediate consumption through which Chungwa's poorer urban youth simulate the lives of the wealthy-the rapid acquisition and expenditure of cash on alcohol and other substances in order to emulate modes of conspicuous consumption normally the preserve of older men who are seen as having 'made it' in life and become visibly 'rich'. It shows how young men in Chungwa Town want to 'get rich quick' - to live in the present as if they had skipped forward through time to an imagined future point in which they themselves are rich. Impatient accumulation and immediate consumption are practices that recognize not merely a temporal gap between young men and their wealthier peers and elders (cf. Mains 2007), but one that is defined by inequality of social status apprehended through a disparity in economic means. Impatient accumulation via theft and 'hustling' practices (Thieme 2018) for the instantaneous consumption of alcohol are ways Chungwa Town youth redress that inequality in the present moment, the here and now-to simulate the pleasurable experiences of drunken spending as if their cash were in abundance.

In emphasizing the role of the desire for conspicuous consumption in orienting the economic lives of central Kenya's urban poor, this article makes a critique of recent and growing anthropological literature on the subject of hope (e.g., Di Nunzio 2019; Kavedžija 2016; Mains 2011; Masquelier 2013; Moore 2011; Pedersen 2012; Schielke 2015), which I see as coming to have something of a theoretical monopoly on similar contexts of economic uncertainty and precarity-what Nauja Kleist and Stef Jansen (2016) call the 'hope boom' in anthropology. While such literature has made important strides toward conceptualizing contexts of unemployment in which youth can do little else than hope for or dream of a better future (see, e.g., Mains 2011; Masquelier 2013; Schielke 2015), I argue that an emphasis on hope as an existential force of productive uncertainty and indeterminacy effectively untethers the notion from the social and economic contexts in which it operates and the concrete desires that these conditions produce, tending to "emphasize the radical potentialities of human agency and human subjectivity" (Moore 2011: 22) in abstract terms. As Stefan Jansen (2016: 451-452) has suggested, such exhortations may tell us more about 
anthropologists' optimism and epistemological commitments than the ethnographic circumstances under discussion.

Following Jansen (2016), an ethnographic approach is argued for here, one that explores how hopes play out in practice as socially shaped expectations. Conceptualizing hope simply as the "belief that something desired may occur in the future" (ibid.: 454; cf. Di Nunzio 2019: 198), I take a more specific interest in the object of hopes possessed by young men in central Kenya-the lifestyles of conspicuous consumption that they hope to lead. Conceiving of these as desires more specifically, I explore what happens when hopes are exhausted while desires persist. The article shows how grueling, low-paid work (particularly on construction sites) fails to provision the types of life these young men hope to lead, causing them to become frustrated, to "give up," in their terms. Instead, they adopt alternative modes of accumulationusually through theft, but also by 'hustling' for immediate expenditure and consumption. Hopelessness is shown to be far more characteristic of Chungwa Town youth, a loss of belief in the possibility that they can one day become rich through honest work.

The effect is to reveal the allure of wealth and conspicuous consumption and the alternative strategies through which marginalized youth attempt to access experiences from which they are otherwise excluded. This has import for an anthropology attuned to the prevalence of global inequality and the lives lived in its wake. As Alain Badiou (2015) has recently written, the expansion of global capitalism has created a concomitant expansion of desires "for the West" - "to share, what is represented, and which is everywhere extolled as Western ease." The results, he suggests, are "local alienations" from images of wealth and "tendencies to copy, with miserable means, Western configurations and lifestyles." Alternative ways of 'reaching for' (in Iregi's terms) the lives of those who cannot be reached (i.e., the wealthy, either locally or in the global beyond) are characteristic of the contemporary moment and warrant the sort of ethnographic attention that embraces classic questions of status and economic practice. Rather than a theory of hope, such analyses can produce a better understanding of the social effects of material lack for interlocutors and their own aspirations, as this article goes on to explore.

To make this argument, I draw on 20 months of fieldwork (January 2017 to July 2018, August 2019) spent in Chungwa and its broader peri-urban milieu on the northern outskirts of Nairobi. While I lived with a host family on the town's outskirts, this article is primarily informed by fieldwork, conversations, and semi-structured interviews with a range of young male interlocutors in Chungwa (in addition to Cash and Iregi) with whom I became friends in 2017. My regular journeys through Chungwa's thoroughfare when traveling to Nairobi for language classes meant that I became a familiar face in town, a 'Kamau', as I was named by local men who worked in the transport industry alongside others who 
'hustled' for cash nearby as shoeshines, market traders, barbers, or simply spent time 'idling', chewing mũgũuka in the presence of their peers. Chance encounters drew me into Cash's friendship group and their lives, our discussions fueled by their interest in my capacity to present their predicament to wider audiences. It is in that spirit that I distributed diaries to my interlocutors in 2017 and 2018 in an attempt to capture the everyday rhythms of their lives, and to provide an opportunity for their reflections on these rhythms to come to the fore. Cash and Iregi provide the main cases I explore in this article, their voices and perspectives echoed in the words of Henry (21), Gaku (22), and Mwathi (27), a member of the youth football (soccer) team I played for throughout my fieldwork.

\section{Mislaid Objects in the Anthropology of Hope}

Like their peers across the Global South, Cash and Iregi are, in a macro-economic sense, 'surplus people'-those whose labor is not required by a global capitalism capable of producing economic growth without an expansion of formal employment (Li 2013). It is this predicament that has generated the raft of 'informal' economic practices characteristic of contemporary urban Africa (Hart 1973), and central Kenya is no exception. Like many of my younger interlocutors in Chungwa, Cash and Iregi are from low-income, low-status families and dropped out of secondary education. They now 'hustle' for small amounts cash (Thieme 2018), doing odd jobs and living ishirini-ishirini-from one 20 Kenyan shillings (KES) coin to the next, in the words of one of my more middle-class interlocutors who looks down on them. Their broad repertoires of income generation combine begging with piecemeal work, characteristic of what they call "life in the street."

Consider, for instance, this entry from 22-year-old Gaku's diary:

6:30 AM-Wakes up do physical training at the field

7:30 AM-Takes breakfast at a hotel and goes to street to buy bhang

8:30 AM-Enters civil work by spending time to clean the buses in Chungwa area

2:00 AM-Lunch time at the huduma [public service] kitchen and after that decide to go home ...

2:30 AM-Back in Street but decide this day to take miraa [khat] and chew

3:30 AM-Decide to go and see my grandmother who stays in Kiambaa area, help her with work at the shamba [lit., garden, plot of arable land] and collects firewood

5:00 PM-Arrival to Chungwa and collects another miraa which cost's only fifty bob then off to the field to watch other's as their [sic] train [for football practice] and this is the time which am also idol [idle] and decide to take bhang 
6:30 PM-back in street and goes to the club which is located back street and takes keg [cheap locally brewed beer] up to 11:00 PM (excerpt dated September 2017)

Iregi's diary reads much the same way:

I started finding money to eat lunch cause time is running and I have no work. I started to move here, there finding something or someone who can just give me anything. When I was in my walk someone asked me do you want work ... I asked what kind of work. He told me it was for carrying sand with a wheerbrow $[$ sic $]$... I asked him how much he was paying and he said he'll give me five hundred shirring [Kenya shilling] ... I said okey ... I did my job until 6 in the evening ... I went back home took a shower[,] went to a pedlar who sells weed bought three of them [pre-rolled joints] went back home to relax and I could say that was my day. (excerpt dated 21 August 2017)

Gaku and Iregi's words speak to staccato lives of uncertain wage hunting (Kalb 2015) and the tendency of young men to spend their earnings on alcohol (njohi), cannabis (bhang), or cheap khat leaves (mũgũuka) as soon as they had been 'found', often to relax in the evenings, see them through the working day, or merely 'push hours'.

In response to such bleak prospects, a growing number of anthropological accounts of the lives of such surplus people have embraced in a variety of ways hope, uncertainty, and contingency as prominent rubrics (see, e.g., Cooper and Pratten 2015; Kleist and Thorsen 2017; Mains 2011; Masquelier 2013; Moore 2011; Pedersen 2012; Schielke 2015; Vigh 2006). Rather than inscribing the lives of the marginalized with a lack of agency, conceding their structural deprivation, anthropologists have emphasized their interlocutors' resilience-their capacity to live meaningfully in the present, against the odds, by embracing uncertainty (Di Nunzio 2019: 3-5, 59). In tandem with attempts to recover an ethnographic appreciation of human life on the economic margins beyond mere subjugation, anthropologists have also sought to underscore the work that marginal interlocutors do to imagine better lives for themselves and their relations. Alongside uncertainty, hope has featured as a new analytic through which such predicaments of economic uncertainty have been grasped, directing further attention toward a human capacity to, in the words of Elizabeth Povinelli (2011: $18,129)$, "endure" and "live otherwise" within a global capitalism.

In anthropology more generally, there is a growing interest in hope as an affect (or an affective state) that makes difficult life livable, retaining a sense of possibility that a better future will arrive some day, if not soon. In this respect, as Nauja Kleist and Stef Jansen (2016: 378) note, the turn toward hope reflects a particularly anthropological ethical sensibility-that of rescuing the human subject's particularity from the conditions of economic constraint it inhabits. 
The scholar's emphasis on hope is to avoid the pessimism that a more political economic or structural account might provide (see, e.g., Comaroff and Comaroff 2000). It entails a listening role for the anthropologist, to embrace and give voice to the horizons of the marginalized. What is at stake is the possibility of human agency, an agency that Kleist and Jansen (2016) suggest some anthropologists have viewed as an ethical commitment to rehabilitate and salvage, connecting with an older anthropological impulse to seek out forms of 'resistance' against dominant structures (Ortner 2016: 61-65). As Jansen (2016: 460) notes separately, many studies of hope in contexts of economic uncertainty underscore possibility, openness, and flux, suggesting that interlocutors dwelling in uncertainty are not merely passive victims of structural forces beyond their control.

For anthropologists apprehending an era of 'jobless growth' in the Global South, hope and possibility have become common themes. Rising aspirations associated with rising GDP growth and growing middle classes co-exist awkwardly with the reality experienced by many: wage hunting in the informal economy for low pay or simply waiting in a state of unemployment with little else to do other than hope (see, e.g., Mains 2011; Sommers 2012). Alcinda Honwana (2012: 4-7) uses the term 'waithood' to describe this predicament experienced by jobless youth, unable to generate the material means to become adult, but retains an emphasis on the 'creativity' of youth living through such circumstances (ibid.: 7; see also Honwana and de Boeck 2005). Consider Adeline Masquelier's (2013) essay on unemployed young graduates in Niger who gather together at tea houses (fadas) to anticipate a better life. Masquelier's analysis of the sociality of the fadas perfectly demonstrates the manifestation of hope as a generalized orientation comprised of conversation, mutual support, and anticipation (ibid.: 487-488). These are men whose desire for state employment has been impacted by the era of structural adjustment and a contracting state (Ferguson 1999). Choosing to stay jobless and wait for something better, fada members (fadantchés) turn to sociality itself for comfort. Tea, Masquelier's (2013: 486) interlocutors say, is the "friend of conversation," a substance that facilitates a more hopeful orientation to a future yet to come. In this regard, the concept of hope overlaps with an ethnographic emphasis on 'boredom' experienced by the unemployed, a situation that is by no means limited to Africa or the Global South (see, e.g., Jansen 2015; Jeffrey 2010; O’Neill 2017).

Even in rather different contexts, the emphasis on hope as indeterminacy and possibility pertains. In his recent ethnography of street life in Addis Ababa, Marco Di Nunzio (2019: 15, 207) emphasizes uncertainty as the principle through which male youth compose their lives, always improvising, 'moving around' in search of opportunity. Unlike Masquelier's interlocutors, these men cannot afford to wait. Exploring his interlocutors' use of petty theft as a means of creating income, Di Nunzio underscores the extent to which his interlocutors' 
lives are defined not merely by their economic marginality, but also by constant innovation, such as new techniques of theft (ibid.: 61-63). "Embracing uncertainty" (ibid.: 195), these youth seek "a chance" whenever it should come their way (ibid.: 204).

Di Nunzio's invocation of chance (cf. Gaibazzi 2015) also recalls another version of hope among marginal persons. In his article "A Day in the Cadillac," Morten Axel Pedersen (2012: 136) demonstrates how his low-income interlocutors traverse the city of Ulaanbaatar to recoup loans given to others or spend the day "relentlessly pursuing new business opportunities." Pedersen insists on using the concept 'hope' (naidvar) to describe this phenomenon as opposed to more common notions of 'fortune' (hishig) that circulate in Mongolia because, "as a poor man's fortune, hope is what people do when they have no firm ground, in the form of a stable economic, religious, or political cosmos, on which to build their ideas of the future" (ibid.: 141). Naidvar is an effect of a type of economic and existential precarity, where there is no stable ground to slowly build on in terms of wealth because in post-socialist Mongolia, every day is defined by a "scramble to secure food, water, and fuel" (ibid.: 137). Without this 'firm ground', Pedersen's interlocutors resort to a type of temporal “'jumping' or 'trampolining'” (ibid.: 144), anticipating a future in which they have been able to "carve out a 'profit'” (ibid.: 147). Pedersen's version of 'hope' (naidvar) always implies an action (ibid.: 146). It is his interlocutors' "stubborn optimism" (ibid.: 145) that sustains their faith in the future as a rather separate point in time-the belief that something will 'turn up', as it were, to improve their situation since, in their anticipation of acquiring 'profit', they have 'preexperienced' what it is (ibid.: 144).

Despite their ethnographic differences, uniting these accounts in an analytical sense is a desire to recover an ethnographic appreciation of human agency and potential in situations of economic uncertainty and precarity. Jansen (2016: 451) has described such accounts as "valorising sparks of indeterminacy, posited in defiant contrast to assumptions of any determination." Emblematic of this tendency is an insistence that interlocutors are not passive in the face of their predicaments, but actively working within them. Masquelier (2013: 472), for instance, seeks to understand how teatime represents a useful means of anticipation, in contrast with "elders who see tea drinking as a frivolous pastime serving no purpose." The 'art of waiting', as she describes it, is characteristic of efforts that fadantchés undertake in order to "continue to produce, to aspire, and to fantasize" (citing Makhulu et al., ibid.: 488). Di Nunzio (2019: 4) seeks to recover an appreciation of the inherent value of his interlocutors' lives from modes of analysis that underscore the structural exploitation of the poor, "caught in the mechanisms governing the reproduction of regimes of political subjugation." "Getting by and surviving are not mere experiences of letting oneself live and breathe," Di Nunzio argues. "They are what ultimately 
enables the actualization of existence as a site of possibility and reversibility" (ibid.). Pedersen (2012: 142) contrasts his approach with Bourdieu's "gloomy" portrait of the "incoherent behaviours" that apparently characterized the lives of first- and second-generation African migrants living in Parisian suburbs. He argues that his interlocutors exploit "virtual potentials in the present," vaulting themselves into more financially certain futures through the "work of hope" (ibid.: 145).

In seeking to recover an ethnographic appreciation of human agency and possibility, such accounts recall arguments made by an older anthropology of marginal life-that spawned by Oscar Lewis's notion of the 'culture of poverty' (see Howe 1998). Only Pedersen's account engages explicitly with this literature, which is exemplified by a pioneering volume entitled Lilies of the Field: Marginal People Who Live for the Moment (Day et al. 1999). In this collection, a set of wide-ranging essays seeks to understand the 'anti-economic' activity of marginal people (conspicuous consumption, gambling, alcoholism, etc.) as an inversion of mainstream economic ideology. Like the anthropologists of hope and indeterminacy, these authors reject the notion that the lives of the marginal are merely an effect of their economic predicament-a maladapted 'culture', in Lewis's original terms. Writing in the book's introduction, its editors argue that 'living for the moment' constitutes a different sort of practical sense, one that values pleasure and happiness in the short term above economizing for the long term (ibid.: 1-3, 20-21).

Despite the volume's many merits, I would suggest that in the editors' introduction, too much is made of 'presentism' as an ideological counter to hegemonic modes of living-the possibility that a life of immediate returns might constitute interlocutors' "defensive stance of nonengagement ... reducing contact with the dominant order to a minimum” (Day et al. 1999: 19). While the editors concede that there is real vulnerability in acts of conspicuous consumption adopted by those on the economic margins, I do not think that enough weight is given to the possibility that conspicuous consumption adopted among marginal persons in the short term could amount to emulating the lifestyles of the wealthy, but with rather more limited means. This is not to fall back to a Bourdieu-style approach that emphasizes the maladaptation of the poor (see Pedersen 2012: 141-142), but rather to understand their desire to partake in lifestyles associated with economic success, wealth, and prestige. This point was made decades ago by Charles Valentine (1968), who argued that rich and poor inhabit the same social world and aspire to the same values and objects of desire that circulate within them. As a recent volume on conspicuous consumption in Africa has deftly shown, consumption can just as easily be a marker of prestige and status as one of 'resistance' toward economizing (Posel and van Wyk 2019). From this perspective, the desire to consume looks rather more like conforming to social norms than defying them. 
As I see it, the anthropology of hope suffers from a related problem-emphasizing the irreducible indeterminacy and flux of the lives of the poor and marginalized without recourse to what I would see as a wider ethnographic inquiry into the ideological 'pull' of short-term consumption. In emphasizing the 'sparks of indeterminacy' as many contemporary accounts of marginal life do, I am not sure that enough attention is being given to the ways in which the economically marginal might hope for certain things that are valued in their immediate contexts, yet access them via rather different means. I would suggest that accounts emphasizing the 'work of hope' in such ways have formalized the workings of hope-viewing it as a “'mode' of existence” (Di Nunzio 2019: 196). And so, while I recognize that hope's indeterminate version appears to be very well-suited to describing the lives of marginal people who live presentist lives, it also sidesteps questions about the situated aspirations, values, and desires of these people in their own terms. In short, the object of hope has disappeared (Berlant 2011).

Consider again Iregi's words with which this article began. Rather than waiting patiently for his fortunes to change or moving around in search of opportunity, they display an impatience-a desire to have wealth to spend on pleasurable consumption, to have fun in the present moment. Iregi had seen the money possessed by his peers from wealthier backgrounds and wanted precisely the same thing. His words warrant a shift in analytical emphasis, away from purely possibilist logics of hope and toward desires not waited forlike dreams in the distant future-but seized in the meantime, in the assault of a passerby. Iregi's words point to a consideration not merely of his mode of living, but of how his desires-acted upon as they are-are structured by glimpses of wealth viewed in the broader social milieu and limited by material constraints. Hope is clearly tethered to desires that he wishes to be fulfilled and that persist, even when they are unlikely to be attained. It is precisely these social dynamics and their social consequences for interlocutors to which I turn in the following section. Rather than an impression of hope as pure possibility, what remains is an appreciation of the allure of consumption and the desire to partake in it via alternative means.

\section{To Get Rich Quick}

In central Kenya, hope in an ethnographic sense can be understood as the belief young men have that they can accomplish normative teleologies of masculine becoming-gaining wealth through work (often involving migration within Kenya and beyond), marrying, having children, and eventually retiring to one's rural homestead permanently. A strong labor ethic permeates the society, exhorting men to work toward the achievement of a patriarchal household 
and to celebrate wealth and success earned through 'hustling' in the informal economy, exploiting opportunity through intelligence and effort. A successful person is regularly said, in glowing admiration, to have "hustled for themselves," while proverbial wisdom scolds the dependent: "He who relies on his relatives dies poor." The problem is, work does not pay.

For the majority of young men in Kiambu and in Kenya more generally, low wages are the norm. Surveys I carried out among young men from Chungwa and its rural environs in 2017 and 2018 revealed that around 500 KES per day could be earned on construction sites as a 'casual laborer' (mjengo), but such work was often irregular. ${ }^{3}$ While carrying out a survey on earnings, I asked Mwathi (27), one of my friends from the football team, "How much can you earn in a week?" "You can't say [Huezi sema]," he answered. Friends of mine who worked on construction sites could earn up to 3,000 KES in a full week of work at the very best-with 1,500 KES for the odd three days being more typical-but they would then go unemployed for months afterward. Piecemeal work at low wages with low buying power was the norm.

With low wages consigning Kiambu men to waiting, their material lack sits uneasily with the gentrification of its southern border shared with Nairobi. The city's expansion northward has brought with it a number of changes-rising land values and the emergence of the desire to sell inherited land or to become rentiers, a growing influx of newcomers to the busy urban rhizome, the building of middle-class apartment blocks, and the construction of enormous new shopping malls that rise out of the landscape like fortresses.

New and visible wealth has created a terrain of "envy behavior" (Foster 1972: 166) and social comparison in which societal stratification and social achievement are keenly observed-by interlocutor and anthropologist alikein the sometimes modest distinctions between persons on the basis of consumption, the evidence that one is living a good life. Kiambu's prosperity has seen the emergence of new types of conspicuous consumption in towns such as nearby Ruaka, which are replete with bars and nyama choma (grilled goat's meat) eateries where middle-aged men, usually in their thirties at least, go to drink beer on weekends. These are men who have 'made it', in the parlance of my interlocutors, who have jobs in Nairobi either in government agencies or in businesses so that they can afford cars and bottled beer at 180 KES-rather unlike the cheap jugs of locally brewed keg beer that poorer youth purchase at 50 KES per cup. As men with incomes and status, they embody not only a middle-class discourse that values wealth production, but also countervailing practices of wealth's consumption for the sake of momentary fun as part of a culture of weekend drinking. Although drinking is condemned in some circles, particularly in its most excessive forms, older and economically successful men are considered to have earned the right to spend surplus wages in this way, since their economic and domestic lives are often seen to be in good order. 
It is in such spaces that young underemployed men like Cash and Iregi encounter not only established figures who represent long lives of economizing practice and eventual success, but also the images of abundance that they create with their drinking. From the perspective of the poor, these men are 'exemplars' (Robbins 2018) of vast wealth spent on partaking in raha-a word that translates simply as 'fun' and yet also evokes a sort of 'free' sociality, typically between men, who come together to drink over the course of a day or night, sharing stories and gossip, mirth, and joy (Marsden 2007; Papataxiarchis 1991). Raha is not simply functional drinking, to forget worries on a short-term basis. It creates an image of abundance evoked by the sight of seeing others spend as if they had no shortage of cash. Raha was, for Cash, "when you're in the club, buying drinks, with girls, whatever."

Quite a few of my own experiences with Cash and his friends involved drinking at bars, funded mostly by myself and his friends from well-up backgrounds with jobs. These were afternoons and then evenings of slow drinking until we would retire to Cash's friends' houses to smoke bhang and listen to dance hall music at ridiculously loud volumes. I sometimes had the sense that the levels of raha that Cash and his friends reminisced about from his younger days when he would go to reggae clubs in Nairobi were never quite reached. Nonetheless, those evenings gave me some sense of what raha was like, even if somewhat tempered. It was a desire to experientially inhabit a desired aesthetic-captured by Magnus Marsden (2007: 474) in his concept of "locally situated social aesthetics" - that characterizes raha, where outward appearances are conjoined with notions of masculine personhood. To experience raha implies the capacity of wealth to facilitate pleasurable experiences of drunkenness that cannot be reduced to outward-oriented performances. Sasha Newell's (2012: 99) similar work on youth 'bluffing' in Côte d'Ivoire describes the performance or demonstration of a "spectacle of wealth" when drinking at outdoor bars (maquis). Newell explores the types of conspicuous consumption in which young men engage in order to perform status outwardly to audiences in a local politics of reputation (ibid.: 106-108, 118). What is underplayed in Newell's account, however, is not only the significance of images of wealth created in this process, but also the subjective, experiential aspect of dwelling in this performance of wealth-which is how I understand raha (see also Van Wolputte and Fumanti 2010: 280).

For Cash and his peers, low wages ruled out hopes that they would ever reach the point in life that having raha implied. "We all want to have a good life, and to have a good life you need money ... If I go to work and get 500how much will I save?" Cash explained, adding, "It's not enough.” Mwathi's words are also useful here. I had been talking to him while we were waiting for a football match to begin in Chungwa Town on a misty morning in April 2018. He had begun asking me about my project and my interest in youth unemployment, and in response he took it upon himself to elaborate the predicament of 
his peers. He took my notebook and began scrawling numbers, breaking down the budgets that young men in construction work live on.

Mwathi: Let's say a guy comes here from Muranga to search for greener pastures. He works three days a week per month that's times by four.

Myself: OK, that's 6,000.

Mwathi: Then his rent is very cheap, like 1,500. Then he has 4,500. 2,500 goes on food, clothes, things you need. Your girlfriend asks for 1,000. Maybe you send some cash to your parents. That's before you've had any fun yourself! That's when you start to take that kanusu.

Taking the 'little half' (kanusu) of Kenya Cane, a popular spirit, was an indication of the loss of hope men experienced when they realized the finiteness of their wages. A popular Gikuyu-language gospel song warns against the effects of illicit alcohol in precisely these terms. Entitled "Njohi cia Ibango" (lit., Wild Alcohol), its singer Muigai wa Njoroge describes how jobless young men have "lost the hope of life" (küaga mwihoko wa maica), that being unemployed is tantamount to being "dead and buried" (ũngĩaga wĩra wĩ mũndũ mũthike mũkuo).

For men like Iregi and Cash, crime was an alternative solution to depleted hope, a "reorientation of hope" in Iza Kavedžija's (2016: 9) terms. The point of stealing was to facilitate experiences in which they could not normally partake-to simulate having skipped forward to an imagined future point in life in which they would (at that point, it was imagined) be rich. "You know most of us guys ain't got no patience," Cash once told me. "Let's say I work in my shop and I work for like two days and I still ain't got much money, I'll want to give up. Most of us guys see those rich guys like, I've got some friends living at Crystal Plaza, these apartments near the market paying $15 \mathrm{~K}$ rent [i.e., 15,000 KES]. $15 \mathrm{~K}$ ! And I'm working the whole month to see that much. You start to lose hope."

Impatient accumulation provides a temporary 'fix' to the problem of hopelessness, rather like how Daniel Mains (2007) describes the way unemployed youth in Addis Ababa enter the visa lottery to travel to the United States or Europe. Mains calls this strategy a "spatial fix" to a "temporal problem"- that of achieving "linear improvement in their relative social position with the passage of time" (ibid.: 668). Impatient accumulation for immediate expenditure has a similar character, particularly when it manifests as theft-appropriating the wealth of another to be "on their level," as Cash put it. The product of frustrations due to the inability to achieve wealth legitimately through work, impatient accumulation also closely resembles the trampolining across time and economic inequality described by Pedersen (2012: 144, 148). Impatient accumulation and immediate consumption were outcomes of a loss of hope that work could provision the lives that young men in Chungwa wanted to lead. Skipping through 
the decades of grueling work and careful saving by taking the cash of others or simply by spending their meager earnings on cheap keg beer and harsh spirits almost instantly were the solutions such men adopted in the interim. In creating these short-term experiences of simulated abundance, they briefly inhabited the lifestyles of the wealthy that they otherwise could not reach, to recall Iregi's words from the article's opening.

An understanding of the ethnographic character of hope as the belief that social expectations can be fulfilled via work allows us to better grasp its consequences as men struggle to live up to their own imaginings of what counts as success, even in a more modest sense. As may have become clear to the reader, most of my interlocutors had, by the point at which I had met them, abandoned their lives of petty crime and were looking back on their pasts with regret. Realizing the short-lived nature of the fun that was possible through theft, men like Cash and Iregi had tried to restore their faith in labor after spending time in prison. However, maintaining this faith was enormously difficult, and lapses back into crime were not unusual.

Henry (21) was another of Cash and Iregi's friends who had lived a similar youth, robbing commuters in Chungwa by night. He had used a common technique known as kupiga watu ngeta (to hit people in the neck). It involved placing a wooden plank under one's sleeve and coming up from behind people, putting them in a headlock and pressing the plank into their neck, which made them pass out. However, by the time I met him, Henry insisted that this was a vestige of "the past life" he had led when he lacked any "options." Understood retrospectively as the product of their lack of options, Chungwa Town youth often rendered their past lives understandable but also distanced themselves from those pasts in moral terms. Yet still, issues with low returns persisted. In September 2017, struggling to make ends meet by selling wristbands at his kibanda (market stall), Henry mugged a drunk man in Chungwa, using the money he stole to drink at a local bar while trying to forget his worries about the police finding him. After trying to go into hiding, Henry was turned in to the police by a witness. He spent several days in a jail cell before being bailed out by his father.

Like Henry, Cash insisted that he had changed, that he had adopted a more legitimate way of making money. In 2017, he opened a small kiosk in Chungwa selling basic household foodstuffs, such as mandazi (a popular doughnut-like snack often eaten at breakfast), loaves of bread, and packets of powdered hot chocolate. Like Henry, Cash often iterated to me-an outsider and a listenerthat he was on his way to better things via more legitimate means. But the reality was somewhat different. Toward the end of 2017, I began to find his shop closed, and I soon learned that he had begun drinking his proceeds rather than investing them in further items to stock. In our private conversations, Cash recognized that this was "not good" and that he needed to be careful with 
the amount he was drinking. Yet he would nonetheless justify this behavior to himself-that it made sense to "have fun" now while young. In a few years, he would become 'serious' (Cooper 2018) and abandon the lifestyle he currently led. But his meager earnings pushed him in the direction of rewarding himself in the short term, recognizing that a 'serious' long life of careful economizing would give him few opportunities to do so until he had almost reached its end. The limitations of his cash made the stakes palpable. It was a choice between fun or the future, with either one obliterating the possibility of the other-until the next day, at least.

\section{Conclusion}

Chungwa Town youth lack the income to afford nights of raha. It is on that basis that my interlocutors appropriated the money of others in a bid to briefly simulate or 'reach for' (gũkinyirra) the lives they could not lead, or simply spent their earnings as soon as they were made. What is at stake for them are not "virtual potentials in the present" (Pedersen 2012: 145). The problem they knowingly and reflexively face is already much more defined than that: it is wealth and the conspicuous consumption it would facilitate. There is no ranging possibility here, no hopeful indeterminacy—only a fundamental problem that itself is structured by the social context in which material lack butts up against images of extravagant wealth, both in situ and in the media. It makes little sense to underscore possibility when the material stakes of everyday economic life are palpably clear to both interlocutor and anthropologist.

The predicament that Chungwa Town youth live is inherent to a global capitalism that produces objects of desire inaccessible to the many. Samuli Schielke (2015) makes precisely this point-that capitalism raises expectations by promising more and new things, that it raises aspirations beyond material limits. This article has drawn attention to the frustrations and attempts to partake in these images of 'ease' (Badiou 2015), material comfort, and economic capacity, despite limited means. This fundamental point-that wealth, even extreme wealth, is desired by those with a material lack-has gone somewhat understated in the literature on hope, possibly because it is unpalatable to anthropologists who prefer instead to see people unlocking more general and generic human potentials.

Anthropologists are hardly ignoring 'ugly emotions' of greed and envy ethnographically (Hughes et al. 2019). Yet further opportunity remains, not only to demoralize desire, but to explore it as an outcome of contexts that ethnographers have ample tools to describe. Attention to accumulation, expenditure, and consumption may yield perspectives as vital as those that emphasize uncertainty and indeterminacy. This article therefore ends with an exhortation to 
anthropologists to maintain an ethnographic focus on how hopes and desires are structured and lived in a world of disparity (Hage 2016), to ensure that our accounts remain grounded in the social and economic rather than the transcendental and that the workings of hope are not stylized beyond the material vagaries our interlocutors may be trying to transcend in the first place.

\section{Acknowledgments}

I would like to thank Harri Englund for his comments on an earlier draft of this article. Discussions and correspondence with Rosalie Allain, Yvan Droz, David Ginsborg, Sophia Hornbacher-Schönleber, Corinna Howland, Nick Lackenby, James Laidlaw, Camille Lardy, Julia Modern, Tom Powell Davies, Joel Robbins, Julian Sommerschuh, Constance Smith, Sofía Ugarte, and Anna Wood have also informed and enriched my approach to this material. I also thank the journal's editor, Martin Holbraad, and the two anonymous reviewers for their helpful suggestions, which greatly contributed to the rewriting of this article. In Kenya, I thank all my friends and interlocutors-anonymized as they are out of ethical considerations-for their immense hospitality, friendship, and understanding of my project. This research was supported by the UK Economic and Social Research Council (grant number ES/J500033/1), and further fieldwork funding was awarded by the British Institute in Eastern Africa in 2017 and the French Institute for Research in Africa (IFRA) in 2018.

Peter Lockwood is a PhD candidate in the Department of Social Anthropology at the University of Cambridge. He conducted doctoral fieldwork in Kenya between January 2017 and July 2018 and again in August 2019 on the peri-urban outskirts of Nairobi. He is currently writing a thesis provisionally titled "Scarcity and the Social Future: A Moral Economy of Continuity and Consumption in Central Kenya." His research encompasses a range of themes: household and family life, land disputes and inheritance, politics and democracy, and the economic lives of young men. His work has appeared in the Journal of Eastern African Studies. E-mail: peteralockwood@gmail.com 


\section{Notes}

1. I use pseudonyms for interlocutors throughout the article and for the town of Chungwa. Unless otherwise indicated, all translations are my own.

2. Throughout 2017 and 2018, when the fieldwork for this article was undertaken, the ratio between KES and USD hovered at 100:1.

3. During this period, I surveyed approximately 25 male youths on their work patterns, incomes, and social and educational backgrounds.

\section{References}

Badiou, Alain. 2015. "Notre mal vient de plus loin” [Our evil comes further]. Là-bas si j'y suis, 3 December. https://la-bas.org/la-bas-magazine/textes-a-l-appui/ alain-badiou-penser-les-meurtres-de-masse-du-13-novembre-version-texte.

Berlant, Lauren. 2011. Cruel Optimism. Durham, NC: Duke University Press.

Comaroff, Jean, and John L. Comaroff. 2000. "Millennial Capitalism: First Thoughts on a Second Coming.” Public Culture 12 (2): 291-343.

Cooper, Elizabeth. 2018. "The Importance of Being Serious: Subjectivity and Adulthood in Kenya." Ethnos 83 (4): 665-682.

Cooper, Elizabeth, and David Pratten, eds. 2015. Ethnographies of Uncertainty in Africa. Basingstoke: Palgrave Macmillan.

Day, Sophie, Evthymios Papataxiarchis, and Michael Stewart, eds. 1999. Lilies of the Field: Marginal People Who Live for the Moment. Boulder, CO: Westview Press.

Di Nunzio, Marco. 2019. The Act of Living: Street Life, Marginality, and Development in Urban Ethiopia. Ithaca, NY: Cornell University Press.

Ferguson, James. 1999. Expectations of Modernity: Myths and Meanings of Urban Life on the Zambian Copperbelt. Berkeley: University of California Press.

Foster, George M. 1972. "The Anatomy of Envy: A Study in Symbolic Behavior.” Current Anthropology 13 (2): 165-202.

Gaibazzi, Paolo. 2015. "The Quest for Luck: Fate, Fortune, Work and the Unexpected Among Gambian Soninke Hustlers." Critical African Studies 7 (3): 227-242.

Hage, Ghassan. 2016. "Questions Concerning a Future-Politics.” History and Anthropology 27 (4): 465-467.

Hart, Keith. 1973. "Informal Income Opportunities and Urban Employment in Ghana." Journal of Modern African Studies 11 (1): 61-89.

Honwana, Alcinda. 2012. The Time of Youth: Work, Social Change, and Politics in Africa. Boulder, CO: Lynne Rienner.

Honwana, Alcinda, and Filip de Boeck, eds. 2005. Makers and Breakers: Children and Youth in Postcolonial Africa. Oxford: James Currey.

Howe, Leo. 1998. "Where Is the Culture in the 'Culture of Poverty'?" Cambridge Journal of Anthropology 20 (1-2): 66-91. 
Hughes, Geoffrey, Megnaa Mehtta, Chiara Bresciani, and Stuart Strange. 2019. "Introduction: Ugly Emotions and the Politics of Accusation." Cambridge Journal of Anthropology 37 (2): 1-20.

Jansen, Stef. 2015. Yearnings in the Meantime: 'Normal Lives' and the State in a Sarajevo Apartment Complex. New York: Berghahn Books.

Jansen, Stef. 2016. "For a Relational, Historical Ethnography of Hope: Indeterminacy and Determination in the Bosnian and Herzegovinian Meantime." History and Anthropology 27 (4): 447-464.

Jeffrey, Craig. 2010. Timepass: Youth, Class, and the Politics of Waiting in India. Stanford, CA: Stanford University Press.

Kalb, Don. 2015. “Class, Labour, Social Reproduction: Towards a Non-Self Limiting Anthropology." Suomen Antropologi 40 (2): 50-55.

Kavedžija, Iza. 2016. “Introduction: Reorienting Hopes.” Contemporary Japan 28 (1): $1-11$.

Kleist, Nauja, and Stef Jansen. 2016. "Introduction: Hope over Time-Crisis, Immobility and Future-Making." History and Anthropology 27 (4): 373-392.

Kleist, Nauja, and Dorte Thorsen, eds. 2017. Hope and Uncertainty in Contemporary African Migration. New York: Routledge.

Li, Tanya M. 2013. "Jobless Growth and Relative Surplus Populations.” Anthropology Today 29 (3): 1-2.

Mains, Daniel. 2007. “Neoliberal Times: Progress, Boredom, and Shame among Young Men in Urban Ethiopia.” American Ethnologist 34 (4): 659-673.

Mains, Daniel. 2011. Hope Is Cut: Youth, Unemployment and the Future in Urban Ethiopia. Philadelphia, PA: Temple University Press.

Marsden, Magnus. 2007. "All-Male Sonic Gatherings, Islamic Reform, and Masculinity in Northern Pakistan.” American Ethnologist 34 (3): 473-490.

Masquelier, Adeline. 2013. "Teatime: Boredom and the Temporalities of Young Men in Niger.” Africa 83 (3): 470-491.

Moore, Henrietta L. 2011. Still Life: Hopes, Desires and Satisfactions. Cambridge: Polity Press.

Newell, Sasha. 2012. The Modernity Bluff: Crime, Consumption, and Citizenship in Côte d'Ivoire. Chicago: University of Chicago Press.

O'Neill, Bruce. 2017. The Space of Boredom: Homelessness in the Slowing Global Order. Durham, NC: Duke University Press.

Ortner, Sherry B. 2016. "Dark Anthropology and Its Others: Theory Since the Eighties.” HAU: Journal of Ethnographic Theory 6 (1): 47-73.

Papataxiarchis, Evthymios. 1991. "Friends of the Heart: Male Commensal Solidarity, Gender, and Kinship in Aegean Greece.” In Contested Identities: Gender and Kinship in Modern Greece, ed. Peter Loizos and Evthymios Papataxiarchis, 156-179. Princeton, NJ: Princeton University Press.

Pedersen, Morten Axel. 2012. "A Day in the Cadillac: The Work of Hope in Urban Mongolia." Social Analysis 56 (2): 136-151.

Posel, Deborah, and Ilana van Wyk, eds. 2019. Conspicuous Consumption in Africa. Johannesburg: Wits University Press. 
Povinelli, Elizabeth A. 2011. Economies of Abandonment: Social Belonging and Endurance in Late Liberalism. Durham, NC: Duke University Press.

Robbins, Joel. 2018. "Where in the World Are Values? Exemplarity, Morality, and Social Process." In Recovering the Human Subject: Freedom, Creativity and Decision, eds. James Laidlaw, Barbara Bodenhorn, and Martin Holbraad, 174192. Cambridge: Cambridge University Press.

Schielke, Samuli. 2015. Egypt in the Future Tense: Hope, Frustration, and Ambivalence before and after 2011. Bloomington: Indiana University Press.

Sommers, Marc. 2012. Stuck: Rwandan Youth and the Struggle for Adulthood. Athens, GA: University of Georgia Press.

Thieme, Tatiana A. 2018. "The Hustle Economy: Informality, Uncertainty and the Geographies of Getting By.” Progress in Human Geography 42 (4): 529-548.

Valentine, Charles A. 1968. Culture and Poverty: Critique and Counter-Proposals. Chicago: University of Chicago Press.

Van Wolputte, Steven, and Mattia Fumanti. 2010. "Last Call for Alcohol: An Epilogue.” In Beer in Africa: Drinking Spaces, States and Selves, ed. Steven Van Wolputte and Mattia Fumanti, 275-280. Münster: LIT Verlag.

Vigh, Henrik. 2006. Navigating Terrains of War: Youth and Soldiering in GuineaBissau. New York: Berghahn Books. 